\title{
BRIC's Education Challenge to Economic Development
}

\author{
Jacira Werle Rodrigues \\ School of Management \\ Faculty of Business \\ The University of New South Wales (UNSW Sydney) \\ Australia
}

\begin{abstract}
This paper presents a comparative analysis of the current education investments from Brazil, Russia, India and China (BRIC). It seeks to evaluate what has been the strategic plan from each country in relation to their education and training agenda to ensure a highly skilled workforce who will maintain and enhance economic growth across these prominent economies. It identifies gaps in the education and training agendas, analyses public expenditure by level of training and raises questions in relation to if their choices are adequate to promote effective economic growth, maintaining successful profiles in the contemporaneous highly competitive global environment. Findings suggest that the BRIC countries have enormous potential to continue their upward economic trend, provided they more equitably invest in education and training. In addition to extra funding, better management practices seem to be essential to elevate the quality of outcomes.
\end{abstract}

Keywords: BRIC, education investments, economic performance, sustainable development

\section{Introduction}

The BRIC countries (Brasil, Russia, India and China) have emerged as a powerful cluster of developing countries and a strong economic lobby group in today's competitive global environment. Despite recent economic volatility in some countries (for example, China and Brazil) the BRIC's position and profile remains strong. Combined, these four countries represent $42 \%$ of the world's population, $26 \%$ of landmass, and $23 \%$ of Gross Domestic Product (GDP) (World Bank, 2017). There is irrefutable evidence of their progress, for instance, being accountable for $40 \%$ of the global growth between 2010 to 2015, according to World Bank (2016, p.30), and currently responsible for one-fifth of global economic activity, equivalent to both the United States and the Eurozone.

To ensure maintenance and consistency of economic growth, assertive education policies are crucial to these economies. The scope of the challenges to be faced is broad, from ensuring universal access to education and improving levels of literacy and numeracy, to fostering higher education and research development towards building a more sophisticated economy. Education has increasingly been recognised as an enabler to economic growth by BRIC countries (Carnoy, Loyalka, Androuschak \& Froumin, 2014). Recent efforts to improve education targets and access have been commended, for example, China's strategies between 1990 and 2010 to decrease the adult illiteracy level by $70 \%$ and increase higher education opportunities by more than five-fold (United Nations Educational, Scientific and Cultural Organization [UNESCO], 2014). Such developments have major implications, not just for education in these emerging economies, but also for their economic growth and the well-being of citizens as a whole.

Considering this context, this investigation focuses on an alysing how the BRIC countries have strategically been directing their public investments in education, its implications and main challenges for economic progression.

\section{Discussion of Findings}

Each BRIC country has constitutionally recognised access to education as a basic right (UNESCO, 2014). However, this is a relatively recent development and indications are that this goal is yet to be adequately achieved. These constitutional recognitions were only adopted in Brazil in 1988 (Brazil Chamber of Deputies, 2010) and in Russia in 1993 (People of the Russian Federation, 2008); relevant amendments were only adopted in India in 2002 (Government of India, 2012) and in China in 2004 (People"s Republic of China, 2004). 
Other factors that have acted as impediments to progress in this area include policy failure, lack of infrastructure, lack of teaching expertise, inefficient management of resources and poor funding structures (Ardichvili, Zavyalova \& Minina, 2012; Awan, 2012; Yuan, 2011). Nevertheless, there are indications of enhancements in education investment, albeit at different rates of improvement across BRIC (Carnoy et al., 2014), in particular in the higher education sector which is seemingly linked to capacity building for the workforce. BRICs growing recognition of its importance is evident in the Fortaleza Declaration made at the Sixth BRICS Summit (BRICS, 2014) when they reassured the "strategic importance of education for sustainable development and inclusive economic growth."

\subsection{Differing Levels of Investment in Education}

It is broadly acknowledged by the literature that investment in education and training intersects with advancement for the private and public good of a nation, the private good being the individual and the public being the society and its economy (Carnoy et al., 2014; Carnoy et al., 2012; Josh \& Yu, 2014; Yuan, 2011). From this perspective, it is supported that assertive investments in education and training are key drivers for emerging economies to ensure sustained economic growth. Among the BRIC countries, findings reveal significant differences in levels of investment and quality of education each of them. This is valuable information about how these countries have been strategically investing to develop their workforce, what will be their possible constraints and future developments. Table 1 provides an overview of BRIC public expenditure on education (as a share of GDP) between 2000 and 2016.

Table 1: BRIC Public Expenditure on Education (\% of GDP)

\begin{tabular}{|c|c|c|c|c|c|c|}
\hline & 2000 & 2005 & 2006 & 2010 & 2012 & 2016 \\
\hline Brazil & 4.8 & 4.1 & 4.3 & 5.1 & 5.3 & 5.7 \\
\hline Russia & 2.9 & 3.7 & 3.8 & 4.6 & 4.1 & 3.6 \\
\hline India & 3.2 & 2.6 & 2.7 & 3.1 & 3.7 & 2.9 \\
\hline China & 2.9 & 2.9 & 3.0 & 3.1 & 4.3 & 4.3 \\
\hline
\end{tabular}

Source: IBGE (2014) and National Bureau of Statistics of China (2017)

Brazil has maintained slightly increased levels of investments in education in recent years, with the highest level of funding across the cluster since 2000. In 2016, the government directed 5.7\% of its total GDP to education (National Bureau of Statistics of China, 2017). UNESCO figures (2014) indicate that, in terms of total budget spend, investment in education increased from $9.5 \%$ in 1999 to $14.6 \%$ in 2012, evidence of Brazil's commitment to this area. According to some researchers (Awan, 2012; Sandoval, 2012; Yuan, 2011), Brazil does not suffer from lack of funding but inappropriate management of the allocated resources, inconsistent quality of the education initiatives, and poor delivery of the required services (World Bank, 2012).

Russia's investment in education, whilst lower than Brazil, also demonstrates a general upward trend with investment rising from $2.9 \%$ in 2000 to a peak of $4.6 \%$ in 2010, but dropping back to $3.6 \%$ in 2016, perhaps an indicator of a changing economy and national priorities. The oscillations in investment in education suggest lack of consistency in the development of a macro human capital development strategy by the Russian government (Ardichvili et al., 2012; Yuan, 2011). UNESCO figures (2014) indicate that, in terms of total budget spend, Russia's investment in education increased from $9 \%$ in 1999 to $12 \%$ in 2012, not dissimilar to Brazil's efforts.

India, like Russia, shows inconsistent trends in education expenditure. However, these oscillations have been more accentuated, falling from $3.2 \%$ in 2000 to $2.6 \%$ in 2005, and then rising to $3.7 \%$ in 2012, then decreasing to $2.9 \%$ in 2016 . With regard to total budget spend, resources for education decreased from $16.3 \%$ to $11.3 \%$ between 1999 and 2012 (UNESCO, 2014).

The reduction of funds has profound implications, especially since India is currently the second most populous country in the globe, with half of its population below the age of 25 and one-third of them below 15 (World Bank, 2014; Organisation for Economic Co-operation and Development [OECD], 2014). Among the BRIC countries, India is by far the nation with the largest number of people to be trained and educated; however, it is the nation with the lowest investment in this strategic area. 
China, also with a large population, has responded differently from India, with investment in education growing steadily, increasing from $2.9 \%$ in 2000 to $4.3 \%$ of total GDP in 2016 (National Bureau of Statistics of China, 2017). The importance of education is demonstrated by the rise in total budget spend from $11.4 \%$ in 1999 to $16.3 \%$ in 2012. Since the 1980s, China has undertaken several educational reforms (Yuan, 2011), including providing more autonomy and financial support for local governments, and permitting the use of non-government funding to support the establishment of private institutions to meet the growing demand for education and training (Ardichvili et al., 2012).

\subsection{Specific Investment Priorities}

A challenge confronting the BRIC countries is determining levels at which $\mathrm{h}$ investment would have the greatest impact in educating a nation, preparing citizens with life skills, building human resources, and training a workforce for economic growth. Table 2 below provides an indication of the total public expenditure on each level of education in the BRIC countries in 2012 and an insight into the diversity of approaches adopted.

Indications are that, around 2012, Brazil prioritised primary (31.3\%) and secondary (44.7\%) education, with lower expenditure on pre-primary (7.6\%) and tertiary education (16.7\%) (UNESCO, 2014). However, the figures in Table 2 do not provide an insight into the changing demographics in Brazil and the implications for education and training. The World Bank Report (2012) suggests that Brazil's demographic profile is under transition with reduction of fertility rates and an ageing population, which are features of developed countries. Consequently, the education system needs to invest in an adult population who will require further training for a well-equipped and capable workforce able to contribute to the country's economic growth and development. Several strategies have been put in place to address gaps including the encouragement of private colleges and universities; large scale inward attraction of trained academics; and outward bound initiatives such as the Brazil Scientific Mobility Program. The latter was established by the Brazilian Government to fund tertiary students to study abroad and build capabilities in disciplines such as science, technology, engineering, and math (STEM).

Table 2: BRIC education expenditure by level

\begin{tabular}{|c|c|c|c|c|}
\hline \multicolumn{5}{|c|}{$\begin{array}{l}\text { Total public expenditure on each level of education } \\
\text { as \% of public expenditure on education (2012) }\end{array}$} \\
\hline & Pre-primary & Primary & Secondary & Tertiary \\
\hline Brazil & 7.6 & 31.3 & 44.7 & 16.4 \\
\hline Russia & 15 & $\mathrm{n} / \mathrm{a}$ & $\mathrm{n} / \mathrm{a}$ & 23.1 \\
\hline India & 1.1 & 23.4 & 37.3 & 37.6 \\
\hline China & 5 & 33 & 23.3 & 38.7 \\
\hline
\end{tabular}

Source: UNESCO (2014)

Education levels in Russia are considerably higher than the other BRIC countries although this may not be reflected in the figures in Table 2 (figures were not available for primary and secondary categories). More informative is the OECD data (2014) which indicates that around 53\% of the population has tertiary qualifications compared to $32 \%$ among the OECD countries. This places Russia amongst countries with the largest number of people with tertiary education in the OECD group. Researchers (Awan, 2012; Yuan, 2011) attribute the high levels of education to the historically high investment during the Soviet regime, under which higher education was free. However, evidence suggests that, post the Soviet Union collapse, Russia has been unable to capitalise on its highly qualified workforce in the transition from a communist to a capitalist economy (Soboleva, 2011). Consequently, there is a mismatch between skills and jobs (Awan, 2012) where highly educated workers, trained during strategic planning for an economy, have been unable to find suitable employment in a changed economy. This has had flow on effects on employment and living standards. Another consequence has been a brain-drain from Russia (Yuan, 2011), resulting in a shortage of qualified workers in some strategic areas such as engineering and science (OECD, 2014) with implications for investment in re-training of the workforce for sustained economic growth.

Figures in Table 2 indicate that the distribution of educational public expenditure in China has been focused on tertiary education, which received $38.7 \%$ of the total budget, in comparison to $33 \%$ for primary education and $23.3 \%$ for secondary education. Ostensibly, this would ensure that China is well placed to develop a highly qualified workforce that would enhance its economic performance. 
However, some researchers, such as Yuan (2011), and Carnoy et al. (2014) are critical and argue that trends in the funding distribution tend to favour a few high-ranking universities, aiming to foster innovation and scientific production. This widens the gap between elite and non-elite institutions - despite heavy investment in tertiary education, the uneven distribution of investment may have further impacts, where only some tertiary institutions can provide high demand qualifications with currency, leaving others with graduates denied equal access to employment in competitive fields.

In relation to India, figures in Table 2 indicate that this country is prioritising funding for secondary education and tertiary training, allocating $37.3 \%$ and $37.6 \%$ of the percentage of the public money respectively (UNESCO, 2014). It could be argued that India's focus would be to train a large workforce in a country with a vast population to sustain the economy (Carnoy, Loyalka, Androushchak \& Proudnikova, 2012). However, the extremely low expenditure on the early years of education (pre-primary at $1.1 \%$ and primary at $23.4 \%$ ), in a country where almost $30 \%$ of the population is in the primary school age cohort, is bound to have implications for literacy levels, access to education and training, poverty cycles and, in the long term, an adequately equipped workforce for sustained economic growth (Carnoy et al., 2012; World Bank, 2014). In addition to huge disparities related to issues such as gender, religion and socio-economic background, Sharma (2013) highlights the geographic disparities and lack of public expenditure on education and infrastructure for people living in rural areas, where disadvantage will stifle human capital and social development.

\section{Implications for the future}

The BRIC countries have presented an overall highly positive economic performance in recent years highlighting the importance of the emerging economies in the international context. The four BRIC countries have demonstrated accomplishments of accelerated economic growth, which are emphasized in particular by the impressive achievements of China. Nevertheless, numerous challenges are related to how they can maintain consistent and widespread growth levels. Such as analysed in this paper, more and better managed public resources are still to be directed to education improvements, as well as the implementation of appropriate policies.

It needs to be acknowledged that the BRIC countries are increasingly pursuing education not only as a goal in and of itself, but also as an enabler to economic development as well as social gains. Increased access to education provides greater numbers of economically productive citizens, which is key to ensuring sustained growth at a level that the BRIC countries have experienced thus far (Carnoy et al., 2014; Hanushek \& Woessmann, 2012; Hanushek, 2013).

Despite these efforts, all the four BRIC countries continue to have specific bottlenecks to address, with India most strongly demonstrating the set of issues to address. It is the country with the youngest population, higher levels of poverty and lower levels of investments in education, especially in pre-primary and primary training. The largest proportion of Indian public resources has been directed to tertiary education which, thus far, is not reaching the majority of the population. In this context, several doubts arise as to whether this is the best macro level strategy to build a competent workforce which, consequently accelerates economic progression. Similar to India, China also has an enormous population to provide adequate training. Regional disparities and funding differences, with some elite institutions receiving greater amount of resources in comparison with non-elite, are part of the issues to be addressed by the Chinese government.

Increased funding was not enough to improve the quality and access to education in Brazil. The Brazilian government has been consistently investing in education, but analysts (e.g., Sandoval, 2012; World Bank, 2012) point out that more than extra funds are necessary to boost the quality of the learning outcomes fostering technological production, innovations and accelerating economic growth. The Russian case can be considered completely atypical from the other BRIC countries. Different from its cluster peers, the Russian population has higher levels of formal training, although scholars (Awan, 2012; Soboleva, 2011) have concluded that the country has been unable to capitalise on this abundance of highly skilled population. Russia, it seems, has witnessed a brain-drain of professionals in areas such engineering, thereby increasing the challenges to maintaining strong rates of economic progress. Overall, the BRIC countries would do well to consider more carefully their commitment to the education agenda if aiming to maintain and enhance their future economic performance. 


\section{References}

Ardichvili, A., Zavyalova, E., \&Minina, V. (2012). Human capital development: comparative analysis of BRICs, European Journal of Training and Development, 26 (2/3), 213-233.

Awan, A.G. (2012), Diverging trends of human capital in BRIC countries.International Journal of Asian Social Science, 2 (12), 2195-2219.

Brazil Chamber of Deputies (2010).Constitution of the Federative Republic of Brazil, 3rd ed, Brasilia, Brazil: Brazil Chamber of Deputies.

BRICS (2014).Sixth Summit: Fortaleza declaration and action plan. Retrieved fromhttp://brics6.itam araty.gov.br/category-english/21-documents/223-sixth-summit-declaration-and-action-plan

Carnoy, M., Loyalka, P., Androushchak, G.,\&Proudnikova , A. (2012). The Economic Returns to Higher Education in the BRIC Countries and Their Implications for Higher Education Expansion. Higher School of Economics Research Paper No. WP BRP 02/EDU/2012. doi: http://dx.doi.org/10.2139/ssrn.2005696

Carnoy, M., Loyalka, P., Androuschak, G., \&Froumin, I. (2014). The Concept of Public Goods, the State, and Higher Education Finance: A View from the BRICS. Higher Education, 68 (3),1-20.

Government of India (2012).The Constitution of India. New Delhi: India: Ministry of Law and Justice.

Hanushek, E.A.\& Woessmann, L. (2012). Schooling, educational achievement, and the Latin American growth puzzle. Journal of Development Economics, 99, 497-512.

Hanushek, E.A. (2013). Economic growth in developing countries the role of human capital.Economics of Education Review, 37,204-212.

Instituto Brasileiro de Geografia e Estatística [IBGE] (2014).BRICS Joint Statistical Publication: 2014.5th ed, Rio de Janeiro, Brasil: IBGE.

Josh, D.K.\& Yu, B. (2014). Political determinants of public health investments in China and India.Asian Politics and Policy, 6 (1), 59-82.

National Bureau of Statistics of China. (2017). BRICS Joint Statistical Publication: 2017. Beijing: China: Statistics Press.

Organisation for Economic Co-operation and Development (2014).Society at a glance 2014: OECD social indicators. Paris, France: OECD Publishing.

People of the Russian Federation (2008).Constitution of the Russian Federation (with the Amendments and Additions of December 30, 2008). Moscow, Russia: Garant.

People's Republic of China (2004).Constitution of the People's Republic of China (full text after amendment on March 14, 2004). Beijing, China: National People's Congress of the People's of China.

Sandoval, L. (2012). The effect of education on Brazil's economic development, Global Majority E-journal, 3 (1),4-19.

Sharma, R. (2013). Poverty and income inequality in India's urban and rural areas. InL. Peilin,M.K. Gorshkov, C. Scalon, \& K.L. Sharma(Eds.),Handbook on Social Stratification in the BRIC Countries: Change and Perspective [pp.455-480]. London, UK: World Scientific.

Soboleva, I. (2011). Patterns of human capital development in Russia: meeting the challenge of market reforms and globalisation. International Journal of Institutions and Economies, 3 (2), 235-257.

United Nations Educational, Scientific and Cultural Organization [UNESCO] (2014).BRICS: building education for the future - priorities for national development and international cooperation. Paris, France:UNESCO.

United Nations Development Programme (2014). Human Development Report 2014. Sustaining Human Progress: reducing vulnerabilities and building resilience. New York, USA: UNDP.

World Bank (2017). World Development Indicators Database. Retrieved from http://data.worldbank.org/indicator/NY.GDP.MKTP.CD?end=2015\&locations=BR-RU-IN-CN\&start=2000

World Bank (2016). Global Economic Prospects: divergences and risks. Washington, DC, USA: World Bank.

World Bank (2014). World Development Indicators Database. Retrieved fromhttp://databank.w orldbank.org/d ata/reports. aspx? source=world-development-indicators

World Bank (2012).Achieving world-class education in Brazil: the next agenda. Washington, USA: World Bank.

Yuan, S.J. (2011), Educational policies and economic growth in BRICs: comparative perspectives, Journal of USChina Public Administration, 8 (2), 188-197 